\title{
Japan boosts proteomics and cell biology...
}

Tokyo

Japan's budget for science and technology is to be substantially increased in the next fiscal year, thanks primarily to a government move to promote industries in areas such as biotechnology, information sciences and the environment.

Particularly marked increases are aimed at developing research into genomics and its applications and into cell biology, which will receive a 12 -fold increase in support for the construction of a national research centre.

The government's budget request for the financial year 2000, which begins on 1 April, was unveiled last week. It contains funding for various projects supported by prime minister Keizo Obuchi's Millennium Project (see Nature 401, 3; 1999), including a proteomics programme to determine the function of proteins through genome sequencing, and a plan to map single-nucleotide polymorphisms in the Japanese population.

Obuchi's project would be funded by a one-off appropriation to develop an infrastructure for telecommunications, science, technology and the environment for the next century. It is expected to total $¥ 301.5$ billion (US\$2.87 billion), and is intended to help Japan establish a sounder economic base.

This will be added to a relatively modest budget request for 2000 , which, at $¥ 3.18$ trillion, is an increase of only 0.8 per cent over this year's science and technology budget.

The budget for genomics, one of the largest beneficiaries of the appropriation,

\begin{tabular}{|c|c|c|}
\hline & $\begin{array}{l}\text { Request } \\
\text { ( } \neq \text { billion) }\end{array}$ & $\begin{array}{l}\text { \% Change } \\
\text { since } 1999\end{array}$ \\
\hline Total budget & $3183^{*}$ & +0.8 \\
\hline $\begin{array}{l}\text { Special appropriation } \\
\text { for economic revival }\end{array}$ & 301.5 & --- \\
\hline Genome science & 81.5 & +205 \\
\hline Brain research & 30.1 & +13.6 \\
\hline Cell biology & 12.0 & +1233 \\
\hline Life sciences & 31.2 & +16.0 \\
\hline Climate research & 30.2 & +314 \\
\hline $\begin{array}{l}\text { Industry/government/ } \\
\text { university collaboration }\end{array}$ & 51.4 & +32.8 \\
\hline
\end{tabular}

*Excluding special appropriation for economic revival

will more than triple to $¥ 81.5$ billion. This includes $¥ 7.4$ billion for the rice genomesequencing project, which is being accelerated (see Nature 401, 102; 1999).

Increased support for genomics is in line with the government's plan to double spending on biotechnology-related research over the next five years (see Nature 400, 389; 1999). It is to inject $¥ 2$ trillion, bringing spending on genomics to at least 0.2 per cent of the country's gross domestic product.

The government plans to launch genome projects that can be carried out at an interministerial level. Five ministries, including the Science and Technology Agency (STA) and the Ministry of International Trade and Industry (MITI), will be involved. Such efforts have previously been carried out by individual ministries.
The cell-biology research budget is to rise by a factor of 12 to $¥ 12$ billion, of which $¥ 10.5$ billion is from the special appropriation.

The money will fund research into the development, differentiation and regeneration of plant and animal cells at the new national research centre, due to be built by 2001, and at two centres for applied genomics and plant genome research.

According to Mitsuru Miyata, editor of the Japanese biotechnology newsletter Nikkei Biotechnology, cell biology was proposed as a priority area in the life sciences in 1997 by Japan's Science and Technology Council, its principal science policy-making body.

"The government has realized the importance of more integrated research into the interactions of genes and cells as a step up from its previous research in molecular biology," says Miyata, adding that he hopes "it will mark a turning point in Japan's biotechnology research".

Increased support for collaboration between industry, government-run research institutes and universities is another main feature of the budget request, particularly with the impending launch of a new technology-transfer bill, based on the 1980 US Bayh-Dole legislation.

The requested budget for 2000 may still not be enough to meet its target of increasing the country’s science spending to $¥ 17$ trillion by 2001 , however - overall science spending is expected to total $¥ 16.7$ trillion during the fiscal year 2000 .

Asako Saegusa

\section{... while France gives more power to the centre}

Paris

French science is to receive a 1.3 per cent increase in funding next year under government budget figures released last week. But this includes a 77 per cent increase in funds directly available to the Ministry of Research for supporting basic research.

This large increase reflects the ministry's desire to increase its control over research spending, and comes as little surprise to those who have been following science minister Claude Allègre's two years in office.

Last year, in an attempt to stimulate research in areas of emerging importance such as genomics, Allègre created the National Science Funds, a centralized fund within the Ministry of Research. Money for this fund rises from FF318 million (US\$50 million) to FF565 million for the 2000 budget. This is earmarked for life sciences, Earth sciences and environmental research.

The overall civil budget for research and development for 2000 is expected to increase

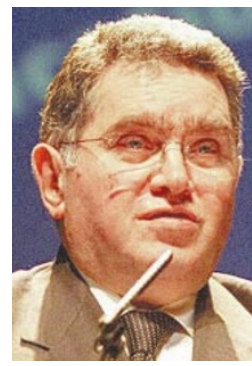

to FF54.6 billion, compared with FF53.9 billion in 1999.

The extra money for the ministry has met with a mixed response. "It doesn't bother me if the government has control over the research," says Pierre Allègre: more control of strategic spending.

Cohen, a member of the National Assembly who headed a

parliamentary commission on French research reforms earlier this year. "But we have always said that it should be transparent and based on principles held by the scientific community."

But unions representing researchers are less enthusiastic. "The government is taking management into its own hands," says Jacques Fossay, a member of SNCS, scientists' main trade union. "There is no input from the scientific community."

While the budget may launch some of the reforms Allègre is enthusiastic about, such as boosting genomics research, there is no money for other promised reforms, such as creating more posts for young researchers.

"There is little creation of employment," says Pierre Papon, a former head of the country's main research agency, the Centre National de la Recherche Scientifique.

The Funds for Technology Research, aimed at boosting research in hightechnology areas, will receive FF905 million, a 35 per cent increase. The money is for research into information and communications technology and for incubating start-up technology companies.

Spending on research laboratories in agencies such as the Centre National de la Recherche Scientifique and the health research agency Inserm will increase by 3.5 per cent, and universities will receive an extra 3.1 per cent for research. Heather McCabe 